\title{
A FIZETÉSKÉPTELENSÉG TERÜLETI JELLEMZŐI MAGYARORSZÁGON ${ }^{1}$
}

\author{
(Regional Features of Insolvency in Hungary)
}

\section{KONDOR ATTILA CSABA}

Kulcsszavak:

fizetésképtelenség csödeljárás felszámolási eljárás vállalkozások területi egyenlötlenségek Magyarország

A tanulmány az 1992-2006 közötti idöszakban inditott csőd-és felszámolási (fizetésképtelenségi) eljárások számának és a regisztrált társas vállalkozásokra vetitett arányának (fizetésképtelenségi arány) földrajzi jellemzőit vizsgálja. A tanulmányban bemutatjuk a fizetésképtelenség területi dichotómiáit, lehatároljuk hazánk fizetöképesség szempontjából kedvezőtlennek minősithető térségeit. Az írás végén a vállalkozássứrüségre és a fizetésképtelenségre vonatkozó adatok segitségével kísérlet történik a "társas vállalkozások terének" tipizálására is. A munka elsősorban leiró jellegü, mindemellett érdekes adalékként szolgálhat Magyarország rendszerváltozás utáni társadalmi-gazdasági folyamatainak komplex elemzéséhez.

\section{Bevezetés}

A magyar gazdaság átalakulásának jeleként már az 1980-as évek elejétől megjelentek az első magánvállalkozások, majd a gazdasági társaságok létrehozását és múködését szabályozó 1988. évi VI. törvény utat nyitott a modern piacgazdaság egyik alapjaként számon tartott gazdasági társaságok megalakulásának is. A piacgazdasági átmenet során számos társas és egyéni vállalkozás a gyakorlatban életképtelennek bizonyult, ezért vált szükségessé az elavult fizetésképtelenségi jog újrakodifikálása. Ennek eredményeként 1991-ben az Országgyủlés megalkotta a csődeljárásról, a felszámolási eljárásról és a végelszámolásról szóló 1991. évi XLIX. törvényt, és ez a jogszabály lett - az 1992. január elsejei hatálybalépés után - a modern magyar fizetésképtelenségi jog alapja. Bár a fizetésképtelenséget szabályozó törvényt többször lényegileg módosították (pl. 1993-ban és 1997-ben), majd 2006-ban az egész fizetésképtelenségi jogot újrakodifikálták (2006. évi VI. törvény), a hazai „csődjog” jellege nem sokban változott; a gazdálkodó szervezetekkel szemben indítható fizetésképtelenségi eljárásoknak 1992 óta két típusa létezik Magyarországon: a felszámolási eljárás és a csődeljárás.

A magyarországi társas vállalkozások (ezen belül különösen a gazdasági társaságok) számának területi vonatkozásait az utóbbi másfél évtizedben sokan vizsgálták, mert - mint a gazdaság területi különbségeinek egy rendkíviul fontos indikátora szinte kihagyhatatlan a regionális fejlettségi kutatások során (pl. Nemes NagyRuttkay 1993; Rechnitzer 1993; Nemes Nagy 1995; Enyedi 1996; Bihari 1999; Nemes Nagy-Németh 2003; Fazekas 2005; Nagy 2006 stb.). Az adathiány miatt 
jóval ritkábban bukkanhatunk a szakirodalomban olyan elemzésre, amely a fizetésképtelenség területi egyenlőtlenségeit állítja a középpontba, ez a kérdés inkább csak járulékos elemként merül fel néhány statisztikai és közgazdasági tanulmányban (pl. Sántha 1999). Az információhiány legfőbb oka az, hogy a bíróságok által a Cégközlönyben közzétett fizetésképtelenségi eljárások számára vonatkozó elsődleges adatforrás napjainkban is a (most már elektronikus) Cégközlöny, illetve az ebben megjelent csőd-, felszámolási és végelszámolási eljárások legfontosabb adatait közzétevő gyorsjelentés, a Heti Csődértesitő. Jelen írásban utóbbi két forrás segítségével igyekszünk felvázolni a csőd- és felszámolási eljárások, valamint az ez alapján számítható fizetésképtelenségi arány területi különbségeit. A munka végén a fizetésképtelenségi arány és a vállalkozássürüség segítségével kísérletet teszünk hazánk kistérségeinek a „társas vállalkozások terében” elfoglalt helyzete szerinti tipizálására is.

\section{A fizetésképtelenség alapfogalmai, a vizsgálat adatbázisa}

A fizetésképtelenségi jog (némileg megtévesztô elnevezéssel: csődjog) feladata, hogy a piaci viszonyok között elégtelenül múködö, eladósodott gazdálkodó szervezeteknek lehetővé tegye az üzleti élet rendjébe való beilleszkedést, vagy ha ez nem lehetséges, megszüntetés útján kivezesse őket a piacról (Miskolczi Bodnár-Török 2002) ${ }^{2}$. Fizetésképtelenség esetén a reorganizációt előtérbe helyező eljárást csődeljárásnak, a megszüntetést célzó és rendszerint megszünéssel is végződő eljárást felszámolási eljárásnak nevezzük. Hazai sajátosság, hogy az úgynevezett „kötelező öncsőd”3 1993-ban történt megszủnése után a fizetésképtelenségi eljárások túlnyomó része felszámolási eljárás ${ }^{4}$. Itt kell felhívni a figyelmet arra, hogy a gazdálkodó szervezetek megszủnésének a fizetésképtelenségen kívül más oka is lehet (p1. elhatározza jogutódlással vagy jogutód nélküli megszủnését, cégbíróság törli vagy megszüntnek nyilvánítja, más szervezetté alakul át stb.). A fizetésképtelenségi eljárások közül csak a felszámolás szünteti meg a vállalkozást, a csődeljárás optimális esetben a hitelezőkkel kötött egyezséggel zárul (amennyiben ez nem így történik, úgy felszámolási eljárás veheti kezdetét). 2006 közepéig, az új csődtörvény hatályba lépéséig a csőd- és felszámolási eljárásokkal egy törvényben szabályozták a végelszámolási eljárást is, azonban ez egy önkéntes megszünési mód, és nem sorolható a fizetésképtelenség körébe.

A csőd- és felszámolási eljárások számára vonatkozóan különbséget kell tenni a bejelentések és a bíróságok által elrendelt eljárások közzététele között, az esetek tekintélyes hányadában ugyanis a csőd- és felszámolási bejelentések adminisztratív véget érnek (pl. visszavonják az indítványt; azt egyszerre többen is megteszik; nem az arra jogosult nyújtja be a kérelmet stb.) (Holló 1994; Reke 1996). Ezért a fizetésképtelenség területi jellemzőinek vizsgálatánál csak a bírósági határozatban elrendelt és a Cégközlönyben közzétett adatokat szabad figyelembe venni. Jelen tanulmány készítése során ez utóbbival számolhattunk, miután a Heti Csődértesitő szerkesztősége felhasználási szerződés keretében rendelkezésünkre bocsátotta a Cég- 
közlönyben 1992. január 1. és 2006. december 31. között megjelent csőd-, felszámolási és végelszámolási eljárások adatait ${ }^{5}$. Az adatbázis felhasználható a fizetésképtelenség térbeli jellemzőinek vizsgálatára, mert a csőd- és felszámolási eljárás alá került cégek székhelyét is tartalmazza. Mivel a csődeljárások száma minimálisra csökkent Magyarországon, a vizsgálatban egységesen kezeltem a fizetésképtelenségi eljárásokra vonatkozó adatokat, hangsúlyozva azt, hogy a fizetésképtelenség 1994 után szinte kizárólag felszámolási eljárást jelent.

A fizetésképtelenségi jog hatálya az úgynevezett „gazdálkodó szervezetekre” terjed ki, ami lényegében egybeesik a statisztikából ismert társas vállalkozás fogalmával; a társas vállalkozások számát a Központi Statisztikai Hivatal minden évben településenként is kőzli ${ }^{6}$. Minden, statisztikai értelemben vett társas vállalkozásra kiterjed tehát a fizetésképtelenségi szabályozás, és helyesen járunk el akkor is, ha a csőd- és felszámolási eljárások számát a regisztrált társas vállalkozások számával vetjük egybe ${ }^{7}$. A két adat hányadosából képezzük a fizetésképtelenség területi jellemzőit plasztikusan bemutató fizetésképtelenségi arányt, ami azt mutatja meg, hogy az adott évben a regisztrált társas vállalkozások hány százalékával szemben indítottak fizetésképtelenségi eljárást. A vállalkozások adatai a Központi Statisztikai Hivatal országos és települési statisztikái segítségével érhetök el; jelen munka írásakor településsoros mutatók csak 2005 végéig álltak rendelkezésre, 2006-ra még csak a vállalkozások országos száma ismert. Mivel a regisztrált társas vállalkozások területi eloszlásában egy esztendő alatt nem következik be „földindulásszerü” átalakulás, ezért a 2005. évi településsoros vállalkozásszám-adatokat - kellő óvatosságal és az adathiányra való utalással - néhány helyen felhasználtuk a 2006-os fizetésképtelenségi arányok bemutatására is.

\section{A fizetésképtelenségi eljárások száma és területi jellemzöi 1992 és 2006 között}

Mint emlitettük, a piacgazdasági viszonyokra szabott új csődtörvény 1992. január elsején lépett hatályba, felváltva a korábbi, még 1986-88-ban hozott felszámolási és „állami szanálási” szabályokat. A rendszerváltozás környékén számos vállalkozás vesztette el a piacát, került likviditási zavarba. A hitelezők védelme és minél teljesebb kielégitése érdekében hozott új törvény 1992-ben valóságos „csődlavinát” indított el: míg az 1986-1991 közötti időszakban csak néhány száz vállalkozás vált (legalábbis jogilag) fizetésképtelenné, addig 1992 tavaszán (a törvény hatályba lépésétöl számított hatvan napos moratórium lejártával) csődbejelentések ezrei özönlötték el a bíróságokat. A csődtörvény hatályának első két évében a fizetésképtelenség kb. 800000 embert, a bruttó termelési érték egynegyedét érintette (Szanyi 1999) ${ }^{8}$. A „,kötelező öncsőd” intézménye miatt 1992-1993-ban több mint tízezer csőd- és felszámolási bejelentés történt, ténylegesen csaknem 8500 eljárás indult. A csódhullám elsődleges okai a gazdaság strukturális válsága, a piaci problémák és a vállalati körbetartozások voltak (Ráday 1993). 
A kötelező csődbejelentés megszüntetése (1993. szeptember 1.) következtében 1994-re lecsengett az elsỏ nagy magyarországi fizetésképtelenségi hullám, részben igazolva azokat a közgazdászokat, akik szerint a fizetésképtelenségi ráta csak papíron volt magas, a cégek egy része csak időlegesen került likviditási válságba, de a kötelező csődbejelentés alól nem tudtak kibújni (Bonin-Schaffer 1996). Mint arról már szó esett, a reorganizációt célzó csődeljárások száma ebben az időszakban magas volt, de 1994 után - így napjainkban is - marginális gyakorlati szereppel bír a felszámolási eljárások mögött. A fizetésképtelenségi - döntően tehát felszámolási - eljárások száma 1995-től újra növekedésnek indult (2006-ban már 9447 eljárás kezdődött, szemben a kilencvenes évek közepi évi 3000-rel). Az előző évihez képest a legnagyobb százalékos növekedés 2000-ben, 2003-ban és 2006-ban volt tapasztalható (1. ábra).

\section{1. ÁBRA}

Csöd- és felszámolási eljárások száma, 1992-2006

(The Number of Bankruptcy and Liquidation Proceedings, 1992-2006)

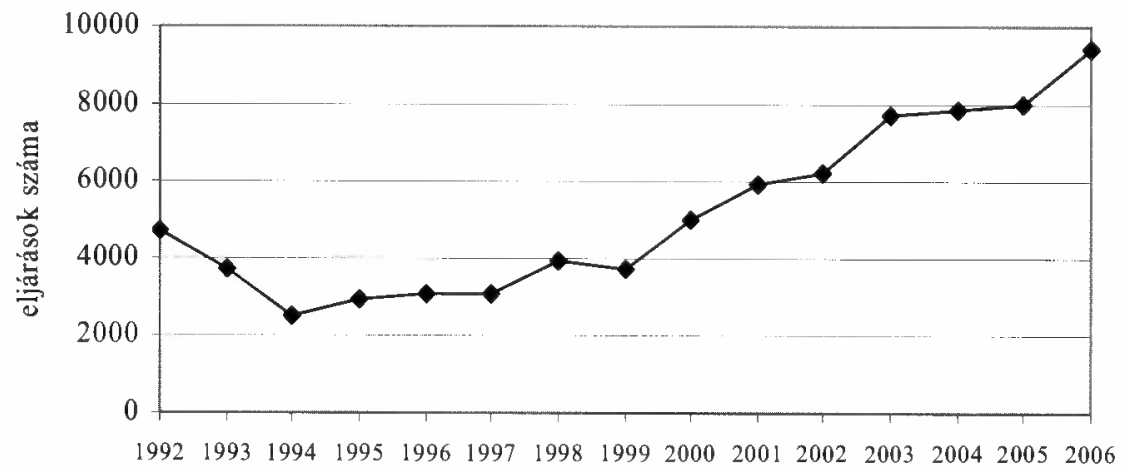

Forrás: Heti Csödértesítő és Cégnet.hu; www.foe.hu

A fizetésképtelenség problémakörének országos méretét mutatja, hogy az ezredfordulót követően a bejegyzett székhelyek szerint ezer fölé emelkedett azon települések száma, ahol fizetésképtelenségi eljárás indult (pl. 2006-ban 1158 olyan település volt, ahol csöd- vagy felszámolási eljárás zajlott; az 1990-es években évente átlagosan 500-600 településen vált fizetésképtelenné társas vállalkozás). Az elmúlt 15 év alatt csupán 761 település társas vállalkozásait nem érintette csőd- és felszámolási eljárás, ezek döntően az ország aprófalvas megyéiben találhatók ${ }^{9}$. A fizetésképtelenségi eljárások abszolút száma - a vállalkozásokhoz hasonlóan - a nagyvárosokban és a fóvárosi agglomeráció területén a legmagasabb, ugyanakkor a társas vállalkozások és a fizetésképtelenség területi eloszlása között már jelentős területi különbségek mutathatók ki. Az 1992-től 2005-ig terjedő időszakban a regisztrált társas vállalkozások székhelyének 40-45\%-a Budapesten volt, de a fỏváros részesedése a csőd- és felszámolási eljárásokból messze ez alatt, 20-35\% között mozgott (2001-ben 19\%-volt, de 2006-ra már 37\%-ra nőtt, megközelítve ezzel a fóváros vállalkozások terén elfoglalt súlyát). Míg a regisztrált társas vállalkozások székhely szerinti súlypontja az elmúlt 
másfél évtizedben folyamatosan Budapest délkeleti határára esett, addig a csőd- és felszámolási eljárások súlypontja (bár újra közelít a fơvároshoz), délkeleti irányban távolabb van Budapesttỏl (2001-ben pl. Pilisen, 2006-ban Vasadon volt). A fizetésképtelenség és a vállalkozások területi megoszlása eltérésének mérésére alkalmazható Hoover-index értéke minden évben jellemzően 20-30\% közötti, ami önmagában is jelentős területi különbségekre utal (2001-ben az index csaknem 35\% volt, 2006-ban - folyamatosan csökkenve - ez az érték $23 \%$ ). A fizetésképtelenség és a vállalkozások regionális különbségei nagyrészt Budapest és környékének a vállalkozások és a fizetésképtelenségi eljárások terén betöltött eltérỏ súlyából fakadnak.

\section{A fizetésképtelenségi arány területi jellemzöi 1992-2006 között}

A „társas vállalkozások terének” regionális különbségeit a fizetésképtelenségi eljárások abszolút számánál jobban megvilágítja az, ha a fizetésképtelenségi eljárásokat a regisztrált társas vállalkozások számára vetítjük. A tört értékét 100-zal szorozva megkapjuk a fizetésképtelenségi arányt, vagyis azt, hogy az adott településen, nagyobb területegységben, vagy éppen országos szinten az adott évben a társas vállalkozások hány százaléka vált fizetésképtelenné.

Magyarország egészét tekintve a fizetésképtelenségi arány 1992-ben volt a legmagasabb: ekkor a közel 140000 regisztrált társas vállalkozás csaknem 3,4\%-a vált fizetésképtelenné. A fizetésképtelenségi eljárások csökkenése és a vállalkozásszám emelkedése miatt 1994-re az „első csődhullám” lezajlott, a fizetésképtelenségi arány 1994-ben már alig haladta meg az 1\%-ot, és az ezredfordulóig lényeges változás ebben nem történt (a csőd- és felszámolási eljárások számával egyenes arányban nőtt a társas vállalkozások száma is). 2000-től kezdődően az országos fizetésképtelenségi arány lassú növekedésnek indult, 2003-ban átlépte a másfél százalékot, és 2006-ban már $1,84 \%$ volt (1. táblázat).

\section{TÁBLÁZAT}

A fizetésképtelenségi arány változása Magyarországon, 1992-2006

(The Change of Insolvency Ratio in Hungary, 1992-2006)

\begin{tabular}{cccc}
\hline$\dot{E} v$ & $\begin{array}{c}\text { Fizetésképtelen- } \\
\text { ségi arány }\end{array}$ & $\dot{E} v$ & $\begin{array}{c}\text { Fizetésképtelen- } \\
\text { ségi arány }\end{array}$ \\
\hline 1992 & 3,36 & 2000 & 1,22 \\
1993 & 2,01 & 2001 & 1,39 \\
1994 & 1,14 & 2002 & 1,40 \\
1995 & 1,14 & 2003 & 1,68 \\
1996 & 1,01 & 2004 & 1,63 \\
1997 & 0,90 & 2005 & 1,60 \\
1998 & 1,04 & 2006 & 1,84 \\
1999 & 0,95 & & \\
\hline
\end{tabular}

Forrás: Heti Cső́dértesitő, www.ksh.hu adatai alapján saját számítás. 
A csőd- és felszámolási eljárás alatt álló regisztrált társas vállalkozások arányának területi megoszlását legcélszerübb megyei, még inkább kistérségi szinten vizsgálni. A regionális szint csak durvább összehasonlításra alkalmas (pl. keleti-nyugati régiók közötti különbségek jellemzésére), míg a települési szintủ vizsgálatok csak néhány esetben, pl. a városi agglomerációk jellemzésekor kezelhetôk fenntartások nélkül ${ }^{10}$. A csődtörvény hatályba lépése utáni évek fizetésképtelenségi arányainak tehát elsősorban megyei és kistérségi szintủ elemzésének eredményeit kívánom ehelyütt összefoglalni.

Az 1992-1993-as fizetésképtelenségi hullám elsősorban Kelet-Magyarországot érintette. 1992-ben a fizetésképtelenségi arány Békés megyében volt a legmagasabb $(6,8 \%)$, de Szabolcs-Szatmár-Bereg, Borsod-Abaúj-Zemplén és Jász-Nagykun-Szolnok megyékben is meghaladta az 5\%-ot, emellett Nógrád megye legtöbb kistérségére is nagyon magas arányok voltak jellemzök. 1992-ben volt olyan kistérség (a Tiszavasvári), ahol a fizetésképtelenségi arány 20\%-nál is nagyobb volt, de ezen kívül további 16 kistérségben a regisztrált társas vállalkozások több mint $10 \%$-a állt fizetésképtelenségi eljárás alatt (a 17 legsúlyosabb helyzetủ kistérség közül csak négy volt dunántúli). 1992-ben 43 településen minden társas vállalkozás fizetésképtelenné vált, ami abszolút rekordot jelentett. Az első nagy fizetésképtelenségi hullám a Nyugat-Dunántúlt, a fövárost és Pest megyét, valamint Hajdú-Bihar megyét kevésbé érintette, itt a fizetésképtelenségi arány jellemzően 3\% (1992), illetve 1,7\% (1993) körül alakult.

1994-re kiegyenlitődés következett be a fizetésképtelenség területi megoszlásában, mondhatjuk úgy is, hogy a korábban kiugró értékek „lefelé nivelláltak”. A kilencvenes évek közepén az alacsony (országosan $1 \%$ körüli) fizetésképtelenségi arányok mellett a korábbi határozott nyugat-kelet különbség elmosódott. Erre az időszakra az északkelet-magyarországi volt szocialista nagyipar, az alföldi mezőgazdasági szövetkezetek és az átmenet környékén ezek bázisán létrejött társas vállalkozások nagy része szinte teljesen megsemmisült, a Dunántúlon és Közép-Magyarországon viszont a rosszabb lehetőségekkel rendelkező vállalkozások egy része fizetésképtelenné vált. Az évtized közepén Veszprém, majd Somogy, Baranya és Tolna megyében is kissé az átlag feletti volt a fizetésképtelenségi arány. Átmenetileg néhány nyugat-dunántúli kistérség is az élbolyba került a megugró felszámolások miatt (pl. a Kőszegi és a Celldömölki kistérség), ugyanakkor a fövárosban és környékén továbbra is nagyon alacsony volt a fizetésképtelenség regisztrált vállalkozásokra vetített fajlagos mutatója (átlagosan $0,5-0,7 \%$ ). A kilencvenes évek második felére tehát inkább a fóvárosvidék dualitás jellemezte a fizetésképtelenségek térbeli alakulását.

1999-től a csőd- és felszámolási eljárások számának gyorsuló növekedésével és az országos fizetésképtelenségi arány romlásával egyidejüleg ismét egyre határozottabb nyugat-keleti dichotómia jött létre (2., 3. táblázat). Míg a Dunántúl és Pest megye kistérségeiben, valamint Budapesten a fizetésképtelenségi arány nem sokat romlott (jellemzően 1\% körül alakult), addig a három kelet-magyarországi régió kistérségeinek zömében a regisztrált társas vállalkozások több mint $2 \%$-a került csődeljárás vagy felszámolási eljárás alá. A leghatározottabb nyugat-keleti különbség 2003-ban és 2004-ben volt; 2004-ben pl. a 42 legrosszabb hazai kistérség közül 35 a Tisza mentén, illetve attól keletre helyezkedett el, és ez a fizetésképtelenségi hullám már nem kerülte el Hajdú-Bihar megyét sem ${ }^{11}$. Az alföldi térségek helyzetét számottevően rontotta az, hogy a mezögazdasági szövetkezetek körében rendkívül magas a felszámolások száma. 
Kondor Attila Csaba : A fizetésképtelenség területi jellemzői Magyarországon.

Tér és Társadalom 21. évf. 2007/2. 95-108. p.

TÉT XXI. évf. 2007 @ 2

Gyors ténykép

101

\section{TÁBLÁZAT}

A fizetésképtelenségi arány és a nyugati határtól való távolság közötti korreláció mértéke, 1992-2006 (kistérségi szintre számolva)

(The Correlation between Insolvency Ratio and the Distance of Western Border 1992-2006, Calculated on the Level of Micro-regions)

\begin{tabular}{cccc}
\hline$\dot{E} v$ & Korreláció értéke & $\dot{E} v$ & Korreláció értéke \\
\hline 1992 & 0,31 & 2000 & 0,55 \\
1993 & 0,07 & 2001 & 0,43 \\
1994 & 0,23 & 2002 & 0,44 \\
1995 & 0,20 & 2003 & 0,53 \\
1996 & 0,00 & 2004 & 0,50 \\
1997 & $-0,06$ & 2005 & 0,39 \\
1998 & 0,18 & $2006^{*}$ & 0,30 \\
1999 & 0,41 & & \\
\hline
\end{tabular}

*a 2005. évi regisztrált társas vállalkozások számával számolva.

Forrás: Saját számítás.

\section{TÁBLÁZAT}

A legmagasabb fizetésképtelenségi aránnyal jellemezhető 40 kistérség eloszlása a nyugati és keleti régiók között, 1992-2006

(The Distribution of the 40, by the Highest Insolvency Ratios Characterized

Micro-regions between Western and Eastern Regions, 1992-2006)

\begin{tabular}{cccl}
\hline Év & $\begin{array}{c}\text { DDR; NYMR; } \\
\dot{E} D R ; K M R\end{array}$ & $\begin{array}{c}\text { DAR; ÉRR; } \\
\dot{E} M R\end{array}$ & $\begin{array}{c}\text { Legmagasabb fizetés- } \\
\text { képtelenségi arány } \\
\text { kistérség neve }\end{array}$ \\
\hline 1992 & 13 & 27 & 20,3 (Tiszavasvári) \\
1993 & 19 & 21 & 7,7 (Vasvári) \\
1994 & 14 & 26 & 7,1 (Jánoshalmi) \\
1995 & 17 & 23 & 4,5 (Sárbogárdi) \\
1996 & 19 & 21 & 6,1 (Sümegi) \\
1997 & 22 & 18 & 4,2 (Enyingi) \\
1998 & 14 & 26 & 4,7 (Mezökovácsházai) \\
1999 & 12 & 28 & 4,0 (Berettyóújfalui) \\
2000 & 4 & 36 & 4,7 (Mátészalkai) \\
2001 & 9 & 31 & 7,5 (Pétervásárai) \\
2002 & 9 & 31 & 4,1 (Polgári) \\
2003 & 8 & 32 & 5,9 (Polgári) \\
2004 & 5 & 35 & 6,1 (Csengeri) \\
2005 & 12 & 28 & 5,7 (Balmazújvárosi) \\
$2006^{*}$ & 14 & 26 & 5,9 (Kisvárdai) \\
\hline
\end{tabular}

*a 2005. évi regisztrált társas vállalkozások számával számolva.

Forrás: Heti Csődértesítő adatai alapján saját számítás. 
Az utóbbi két évben a nyugat-kelet megosztottság kissé mérséklödött: a továbbra is alacsony fizetésképtelenségi rátával jellemezhetö északnyugat-dunántúli és Pest megyei kistérségek mellett az országos átlagnál jobb a helyzet Bács-Kiskun és BorsodAbaúj-Zemplén megyék kistérségeiben is ${ }^{12}$, ugyanakkor például több délnyugatdunántúli, illetve Komárom-Esztergom megyei mikrorégióban az országos átlag feletti a fizetésképtelenségi arány (2. ábra). Ugyanakkor a nyugat-keleti különbségek fokozódása irányába hat az az új jelenség, miszerint 2006-ban az ukrán határ környéki településeken csaknem 150, a cégnév alapján javarészt vélhetỏen ukrán tulajdonban álló társas vállalkozás ellen indítottak felszámolási eljárást (pl. Kisvárda: 105, Tiszabezdéd: 31 , Záhony: 14$)^{13}$.

\section{2. ÁBRA}

A fizetésképtelenségi arány 2005-ben, kistérségi szinten (The Insolvency Ratio in 2005, on the Level of Micro-regions)

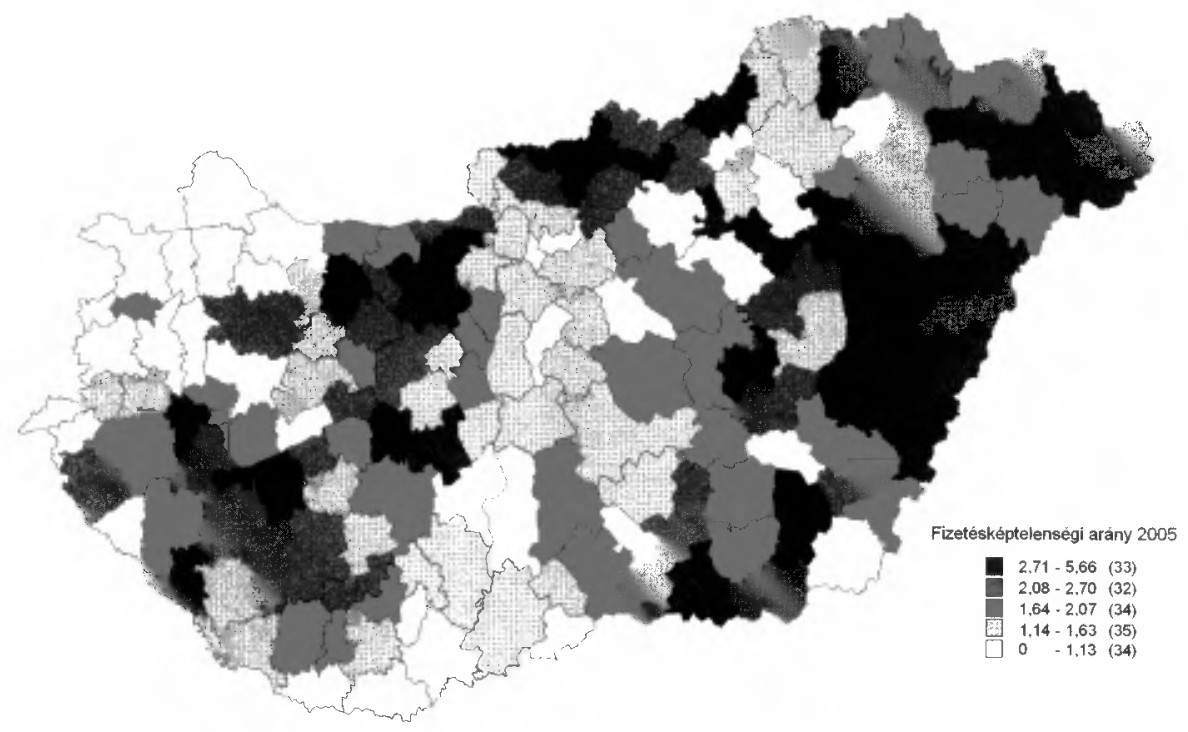

Forrás: Saját szerkesztés.

A csödtörvény hatályba lépése óta eltelt időszakban a fizetésképtelenségi arány tekintetében (hasonlóan több fejlettségi mutatóhoz) nyugat-kelet, illetve centrumperiféria különbséggel jellemezhető térszerkezet alakult ki. 1992-2006 között az éves fizetésképtelenségi arány terén a kelet-magyarországi kistérségek rosszabb mutatókkal rendelkeztek, mint dunántúli és közép-magyarországi társaik. Ha megvizsgáljuk, hogy egy adott kistérség (a jelenleg érvényes kistérségi határokat alapul véve) hányszor tartozott az éves fizetésképtelenségi arány felső quartilisába (a legrosszabb 25\%-ba), akkor a fenti kijelentéseinket alátámasztó adatsorhoz jutunk, amely térképen is ábrázolható (3. ábra). 
Kondor Attila Csaba : A fizetésképtelenség területi jellemzői Magyarországon.

Tér és Társadalom 21. évf. 2007/2. 95-108. p.

TÉT XXI. évf. 2007 a 2

Gyors ténykép

103

3. ÁBRA

A legmagasabb fizetésképtelenségi aránnyal biró kistérségek, 1992-2005

(a jelenlegi kistérségi beosztásra számolva)

(By the Highest Insolvency Ratios Characterized Micro-regions, 1992-2005

[Calculated on the Level of Actually Classification of Micro-region])

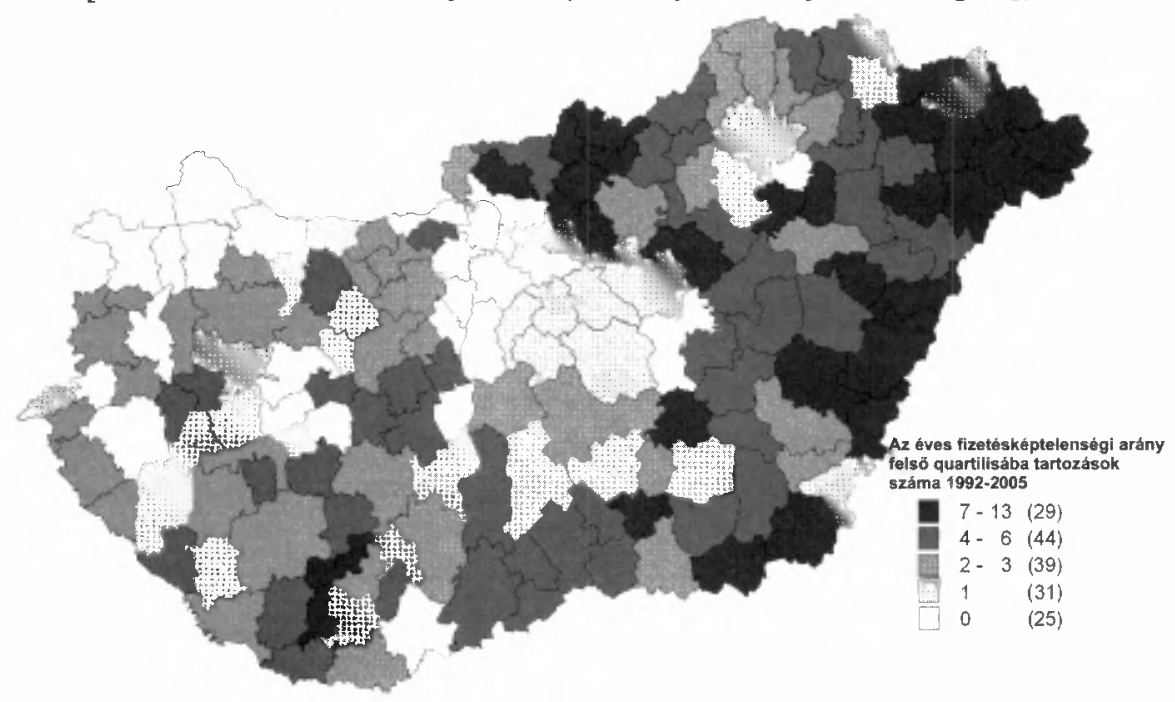

Forrás: Saját szerkesztés.

1992 és 2005 között 29 olyan kistérség volt, amelyik a 14 esztendỏ alatt legalább 7 évben a fizetésképtelenségi arány felső quartilisába tartozott. Ezek közül két dunántúli kistérség (a Sásdi és a Szentlörinci) kivételével a legrosszabb fizetésképtelenségi arányokkal rendelkező kistérségek a Dunától keletre helyezkednek el, és a 29 legrosszabb kistérség közül 21 a Tisza mentén, illetve attól keletre található ${ }^{14}$. Ezzel szemben az a 25 kistérségünk, amelyik egyik évben sem esett a fizetésképtelenségi arány felső quartilisába, jellemzően a Dunántúlon, illetve a fỏvárosi agglomerációban helyezkedik el, és közülük csak kettő, a Szolnoki és a Tiszaújvárosi kistérség van Kelet-Magyarországon. A két szélső csoport közötti kistérségek csak néhány évben számítottak a leggyengébbek közé, mindemellett az ilyen „billegö" mikrorégiók közül a gyengébbek inkább Kelet-Magyarországon, a jobbak inkább Nyugat-Magyarországon találhatók.

\section{A fizetésképtelenségi arány és a vállalkozássürüség kapcsolata}

Míg a társas vállalkozások népességre vetített aránya (a vállalkozássủrủség) elsősorban az urbanizált régiókban a legmagasabb (kivétel ez alól a Balaton térsége), addig a fizetésképtelenségi arány kevésbé fuigg a városodottság szintjétöl. Ez abból is eredeztethetö, hogy míg a vállalkozások és a különböző gazdaságstatisztikai mutatók között erős korrelációs kapcsolat van, addig a vizsgálatok szerint a fizetés- 
képtelenségi arány és a fajlagos jövedelmi-foglalkoztatási adatok ugyan fordított irányú, de jellemzően gyenge együttmozgást tanúsítanak. Mint láttuk, az elmúlt másfél évtized adataival elvégzett számítások szerint a fizetésképtelenségi arány a nyugati határtól való távolsággal nő, míg a vállalkozássürüséget nem a nyugati határtól, hanem inkább a fövárostól (és tegyük hozzá: a nagyvárosoktól) való távolság határozza meg (jellemzően -0,4 körüli korrelációs együttható).

A fizetésképtelenségi arány és a vállalkozássürüség segítségével különböző térségtípusokat alkothatunk, aminek alapján a „társas vállalkozások terében” kedvezö, illetve kedvezőtlen helyzetủ területeket különböztethetünk meg. A két mutató alapján az a területegység mondható kedvező helyzetben lévőnek, ahol a vállalkozássürúség az országos átlag felett van, a fizetésképtelenségi arány pedig nem éri el az országos átlagot. Ugyanakkor a fóváros kiemelkedő súlya az országos átlagokat jelentősen befolyásolja (a vállalkozássürüségét növeli, a fizetésképtelenségi arányét csökkenti), ezért helyesebb a térségtipizálás során mindkét esetben a vidéki átlaggal számolni. A vállalkozássürủség és a fizetésképtelenségi arány egymásra vetítésével látható, hogy 2005-ben a föváros és környéke, valamint az elsősorban a Tiszától nyugatra elhelyezkedő, nagyvárossal rendelkező kistérségek voltak a legjobb helyzetben (4. ábra). Az országos átlaghoz képest is kiugróan magas vállalkozássűrüséggel jellemezhető fỏvárosi agglomeráció (60-118 regisztrált társas vállalkozás/1000 fö) fizetésképtelenségi aránya messze a vidéki átlag alatt marad. A föváros és szűkebb régiója mellett ez az összefüggés elsősorban a nagyvárosokra és agglomerációjukra jellemző, emellett meg kell jegyezni azt a tényt, hogy a dunántúli regionális centrumok (Pécs és Győr), valamint környezetük a fizetésképtelenség tekintetében 2005-ben, de az elmúlt 6-8 évben sokkal jobban teljesítettek, mint Miskolc, Szeged, de különösen Debrecen.

A fizetésképtelenségi arány korábban említett területi különbségeivel magyarázható, hogy míg Pest és Bács-Kiskun megyék keleti határától nyugatra a kis vállalkozássűrủséggel rendelkező vidéki kistérségekben a fizetésképtelenségi arány jellemzően messze nem éri el a vidéki átlagot, addig a fent említett két megyétöl keletre a zömmel alacsony vállalkozássủrüséggel rendelkezö kistérségekben a fizetésképtelenségi arány az országos átlag feletti. Ezek azok a válságrégiók, amelyek a legtöbb térségtipizálás szerint a legfejletlenebb területei Magyarországnak (meg kell említeni azt a tényt is, hogy néhány délnyugat-dunántúli kistérség kivételével általában évröl-évre módosul a kedvezőtlen fizetésképtelenségi mutatókkal bíró dunántúli és Duna-Tisza közi mikrorégiók köre (,billegö kistérségek”), ugyanakkor KeletMagyarországon a helyzet évek óta változatlan). A vállalkozássürüség és a fizetésképtelenségi arány tekintetében tehát a legkedvezőtlenebb térségtípusok Nógrád, Szabolcs-Szatmár-Bereg, Hajdú-Bihar, Békés és Csongrád megyében gyakorlatilag összefüggő területet képeznek, míg a Dunántúlon számottevő koncentráció nélkül vannak jelen. A kutatás által felölelt 15 év mindegyikére elvégzett térségtipizálás alapján kijelenthető, hogy az ismertetett térszerkezet nemcsak 2005-re, hanem az elmúlt másfél évtized egészére jellemző. 


\section{4. ÁBRA}

A fizetésképtelenségi arány és a vállalkozássürüség kapcsolata 2005-ben (The Relationship between Insolvency Ratio and Density of Ventures 2005)

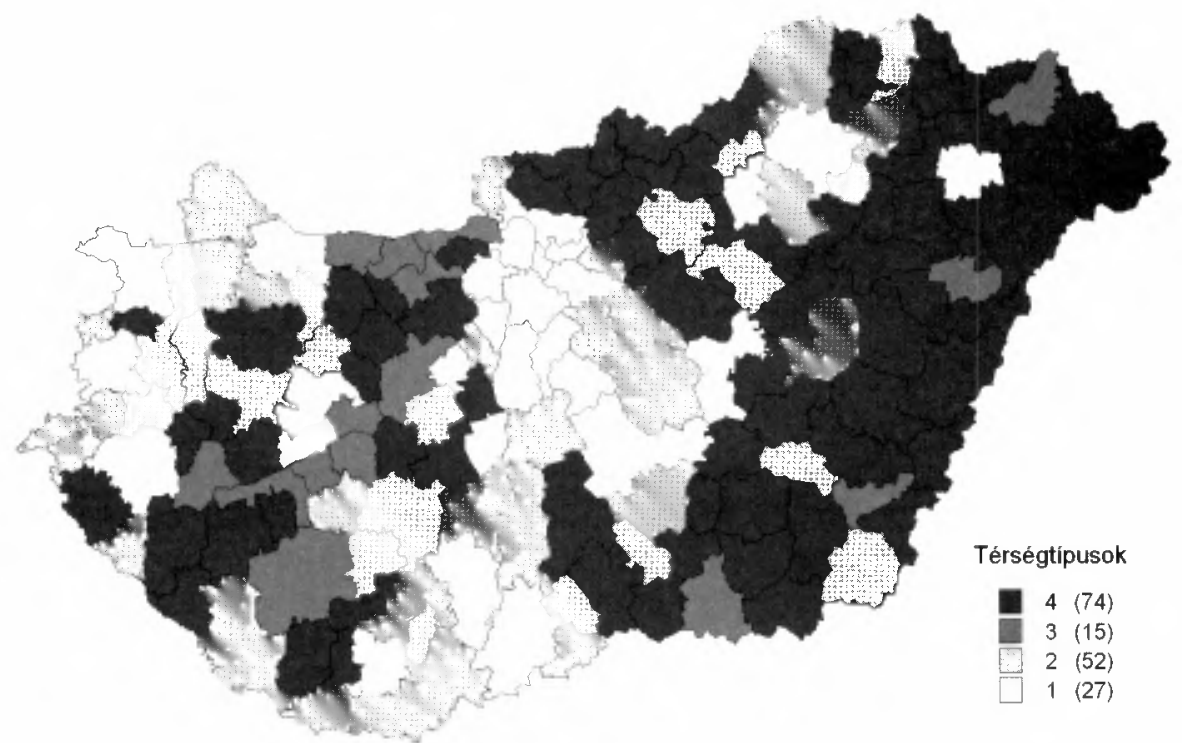

Jelmagyarázat: 1 = fizetésképtelenségi arány vidéki átlag alatt, vállalkozássürüség vidéki átlag felett $2=$ fizetésképtelenségi arány vidéki átlag alatt, vállalkozássủrüség vidéki átlag alatt 3 = fizetésképtelenségi arány vidéki átlag felett, vállalkozássürüség vidéki átlag felett $\mathbf{4}=$ fizetésképtelenségi arány vidéki átlag felett, vállalkozássürüség vidéki átlag alatt.

Forrás: Saját szerkesztés.

\section{Összefoglalás}

A csőd- és felszámolási eljárások számának növekedése a vállalkozásszám emelkedésének velejárója, mert a fizetésképtelenség a modern piacgazdaságban természetes jelenség. Ugyanakkor amint láttuk, az 1993-tól 1-2\% körül mozgó országos fizetésképtelenségi arány területileg meglehetősen differenciált. A csőd- és felszámolási eljárások számának regisztrált társas vállalkozásokra vetített aránya alapján megállapítható, hogy az elmúlt másfél évtizedben a legkedvezőbb helyzetben a föváros és környéke, valamint a nyugat-magyarországi megyék, kistérségek vannak. Kelet-Magyarországon, nagyjából Pest és Bács-Kiskun megyék határától keletre a fizetéskẻptelenségi arány jellemzően magas. Ez utóbbi terület kedvezőtlen gazdasági helyzetéhez az alacsony vállalkozássủrúség is hozzájárul, így a legkedvezőtlenebb helyzetben levő kistérségek zömét itt találjuk.

Azt, hogy adott területegységben (településen, kistérségben, megyében) a regisztrált társas vállalkozások hány százaléka ellen folyik fizetésképtelenségi eljárás, számtalan, részben matematikailag nehezen mérhetó társadalmi, politikai, valamint a gazdasági-vállalkozói környezetben rejlő tényező határozza meg. Látjuk, hogy fizetés- 
képtelenség tekintetében is Kelet-Magyarország rosszabb helyzetben van az ország többi részénél, de a fizetésképtelenségi arány területi különbségeinek magyarázatánál nem támaszkodhatunk kizárólagosan a hozzáférhető gazdaságstatisztikai adatokra. Az okok sokfélék lehetnek: a rosszabb gazdasági helyzet (pl. a nyugati tőke hiánya, alacsonyabb jövedelemszint stb.), a mezőgazdaság permanens válsága, a vállalkozói kultúra relatív fejletlensége mind-mind köđrejátszhatnak egyes térségek vállalkozásainak fizetésképtelenségében. Ebben a tanulmányban a fizetésképtelenség térbeli egyenlötlenségeinek elsősorban leíró jellegü, de talán ebben a formában is hiánypótlónak mondható bemutatására tettünk kísérletet, a mélyben rejlö okok, folyamatok feltárására és elemzésére további kutatásokra van szükség.

\section{Jegyzetek}

${ }^{1}$ A tanulmány a Heti Cső́dértesítő, valamint a Cégnet.hu gyüjtösite támogatásával készült.

${ }^{2}$ A külföldi jogokban általában csödeljárásnak nevezik a vállalkozás megszüntetését célzó eljárást. Magyarországon a korábbi szocialista „szanálási jog” folyományaként fennmaradt a felszámolási eljárás fogalma, és nálunk ennek az eljárásnak a célja a vállalkozás megszüntetése. A köznyelvben (és a jogi szakzsargonban is) csőd fogalma alatt általában a fizetésképtelenséget értik, és a fizetésképtelenségi eljárásokat szabályozó tơrvényeket (1991. évi XLIX. tv., 2006. évi VI. tv.) összefoglaló néven csödtörvénynek nevezzük.

${ }^{3}$ A kởtelezö öncsöd lényege az volt, hogy az adós (az a gazdálkodó szervezet, amely tartozását/tartozásait az esedékességkor nem tudta, vagy - az egy éven belül esedékessé váló tartozásait elöreláthatóan nem tudja kiegyenlíteni) automatikusan csódeljárást kezdeményezett önmaga ellen.

4 A közzétett csődeljárások száma 1992-ben 2922, 1993-ban 984 volt, majd 1994-től kezdve ez a szám száz alá csökkent. Napjainkban a közzétett csödeljárások száma nem éri el az évi ötvenet.

${ }^{5}$ A Heti Csődértesítöt szerkesztő OVI-n (Országos Vezetóképzỏ Intézet Kft.) kívül több cég is gyủjti a fizetésképtelenségi eljárások adatait. 2007 elején pl. a Creditreform Magyarországi Hitelezővédelmi Szövetség is közzétette a fizetésképtelenségi eljárások számát 1996 és 2006 közötti időszakra vonatkozóan. A Creditreform adatai 2000-tól kezdve szinte teljesen megegyeznek a Heti Csődértesítővel, 1996 és 2000 között van néhány százalékos külőnbség az egyes évek adatai között, ami részben abból is adódhat, hogy az eljárás bíróság általi elrendelésének és a Cégközlönyben történö közzétételének időpontját (amely néhány esetben eltéró évre esik) a két forrás különbőzö esztendőkhöz számolta.

${ }^{6}$ A gazdálkodó szervezet fogalma az 1991. évi XLIX. tv. eredeti 3. §-a szerint: „az állami vállalat, a tröszt, az egyéb állami gazdálkodó szerv, a szövetkezet, a gazdasági társaság, az egyes jogi személyek vállalata, a leányvállalat, az önkormányzat vállalata, a víziközmủ társulat kivételével a vízgazđálkodási társulat". A felsorolás az évek során bővült, és a 2006. évi VI. tv. a következő meghatározást tartalmazza: ,gazdálkodó szervezet: az állami vállalat, a tröszt, az egyéb állami gazdálkodó szerv, a szövetkezet, a lakásszövetkezet, a gazdasági társaság, az európai részvénytársaság, a közhasznú társaság, az egyes jogi személyek vállalata, a leányvállalat, a vízgazdálkodási társulat (a víziközmü-társulat kivételével), az erdőbirtokossági társulat, az önkéntes kölcsőnös biztosító pénztảr, a magánnyugdíjpénztár, az egyesülés, ideértve az európai gazdasági egyesülést is, a végrehajtói iroda, a sportegyesület, valamint mindazon jogi személyek vagy jogi személyiséggel nem rendelkező gazdasági társaságok, amelyek fó érdekeltségeinek kőzpontja a Tanács fizetésképtelenségi eljárásokról szóló 1346/2000/EK rendelete alapján az Európai Unió területén található."

A KSH-nómenklatúra alapján regisztrált társas vállalkozásnak minősül a gazdasági társaság, a szövetkezet, az egyéb jogi személyiségú vállalkozás, az állami gazdálkodó szervezet és egyéb vállalat, a jogi személyiség nélküli egyéb vállalkozás, a megszünő gazdálkodási formákkal (pl. gmk-k) együtt. A regisztrált vállalkozásokat a KSH két részre bontja: egyéni és társas vállalkozásokra, amelyek közül csak a társas vállalkozások állhatnak fizetésképtelenségi eljárás alatt. Társas vállalkozásokon kívül 1997 töl, a csödtörvény hatályának kiterjesztésétől kezdve csupán néhány nonprofit szervezet (kht.) került felszámolás alá, így a nonprofit szervezeteket kihagyhatjuk a vizsgálatból. 
${ }^{7} \mathrm{~A}$ regisztrált társas vállalkozás a megfigyelés időpontjában az adminisztratív nyilvántartások szerint jogilag létezỏ egység, azaz adószámmal rendelkezö társas vállalkozás, beleértve az adott időpontban csöd-, felszámolási és végelszámolási eljárás alatt állókat is. A fizetésképtelenségi eljárás alatt álló vállalkozások csak egy bizonyos hányada számolható az adott évben a müködő (foglalkoztatottal és/vagy árbevétellel rendelkező) társas vállalkozások körébe, ezért kell a regisztrált vállalkozások adatával számolnunk.

${ }^{8}$ Ezekben az években vált ténylegesen fizetésképtelenné és került elsősorban csődeljảrás alá a nagy foglalkoztatotti létszámmal bíró állami vállalatok zöme.

${ }^{9} 2005$. december 31 -én 55 olyan település volt az országban, ahol 1992 után egyetlen társas vállalkozást sem regisztráltak.

${ }^{10}$ A települési szintủ vizsgálatokkal nagyon óvatosan kell bánni, mert még az utóbbi évek átlagát tekintve is évente „,csak" $1100-1200$ az olyan települések száma, ahol az oda bejelentett társas vállalkozásokkal szemben fizetésképtelenségi eljárás zajlik. Általában elmondható, hogy kistelepüléseink túlnyomó többségében nincs fizetésképtelenségi eljárás, illetve amennyiben van, abban az esetben az adott település fizetésképtelenségi aránya rögtön az országos élbolyba kerül (a csőd- és felszámolási eljárásoknak évente átlagosan csak 2-3\%-a érint 1000 fönél kevesebb lakosságú települést).

${ }^{11}$ Pl. Debrecenben 2003-ban és 2004-ben 428, illetve 385 fizetésképtelenségi eljárás zajlott, míg ugyanekkor Szegeden 230 és 246, Miskolcon, Pécsen és Nyíregyházán 180-190 volt a csőd- és felszámolási eljárások száma. Ugyanekkor pl. Gyớrben csak 101, illetve 121 eljárást indítottak.

12 Bács-Kiskun megyében átlagon felüli, Borsod-Abaúj-Zemplén megyében átlag alatti vállalkozási aktivitás mellett javult a fizetésképtelenség. Az okok nagyon sokfélék lehetnek: Bács-Kiskun megye esetében a fekete- és szürkegazdaságból származó bevételeknek lehet szerepe a fizetésképtelenség javulásában, míg Borsod-Abaúj-Zemplén megye esetében az alacsonyabb vállalkozási aktivitás eredményezheti azt, hogy bizonytalan kimenetelü és potenciálisan fizetésképtelenné váló vállalkozásba kevésbé vágnak bele az ott élök.

${ }^{13}$ Ugyanakkor Kisvárda és Tiszabezdéd esete felhívja a figyelmet arra is, hogy a fizetésképtelenség hirtelen megugrása nem biztos, hogy általános recesszió miatt következik be, hanem az esetek jelentös részében egy-egy vállalkozónak (vagy vállalkozói csoportnak) a fizetésképtelenné válásáról és az általuk mükơdtetett több tucatnyi bt., kft. felszámolásáról lehet szó. Ennek statisztikai hatása jelentósen torzíthatja az egyenlótlenségi modelleket.

${ }^{14}$ A 2006-os fizetésképtelenségi arányok a vázolt képet nem módositták, de várhatóan a Sellyei, a Pétervásárai és a Zalaszentgróti kistérségek is a fizetésképtelenségi arány felsó kvartilisába kerülnek, és ezzel ez a három kistérség is elémé a 4. ábrán a legrosszabb kategória alsó határának vett 7-es elemszámot.

\section{Irodalom}

Bihari Zs. (1999) Vállalkozási intenzitás a budapesti agglomerációban. - Barta Gy.-Beluszky P. (szerk.) Társadalmi-gazdasági átalakulás a budapesti agglomerációban. Regionális Kutatási Alapitvány, Budapest. 143-154. o.

Bonin, J.P.-Schaffer, M.E. (1996) Bankok, vállalatok, rossz hitelek és csődök Magyarországon 19911994. - Közgazdasági Szemle. 2. 93-113. o.

Enyedi Gy. (1996) Regionális folyamatok Magyarországon. - Ember-Település-Régió. Hilschler Rezső Szociálpolitikai Alapítvány, Budapest.

Fazekas K. (szerk.) (2005) A hely és a fej: munkapiac és regionalitás Magyarországon. MTA Közgazdaságtudományi Intézet, Budapest.

Holló M. (1994) A csőd- és felszámolási eljárások tapasztalatai. - Ipari Szemle. 1. 40-43. o.

Miskolczi Bodnár P.-Török G. (2002) A magyar csódjog alapjai. HVG-ORAC Lap- és Könyvkiadó Kft., Budapest.

Nagy G. (2006) A magyar gazdaság területi folyamatainak mérlege: erősödő területi különbségek, vs. regionális kiegyenlítödés. - Kiss A.-Mezösi G.-Sümeghy Z. (szerk.) Tảj, környezet, társadalom. Ünnepi tanulmányok Keveiné Bárány Ilona professzor asszony tiszteletére. SZTE Éghajlattani és Tájföldrajzi Tanszék; SZTE Természeti Földrajzi és Geoinformatikai Tanszék, Szeged. 529-540. o.

Nemes Nagy J. (1995) A ,gazdasági egészség" földrajzi képe Magyarországon. - Földrajztanitás. 3-4. 4-11. o. 
Nemes Nagy J.-Németh N. (2003) A "hely" és a ,fej": a regionális tagoltság tényezói az ezredforduló Magyarországán. MTA Közgazdaságtudományi Kutatóközpont, Budapest.

Nemes Nagy J.-Ruttkay É. (1993) Vállalkozások területi terjedése (1982-1991), - Enyedi Gy. (szerk.) Társadalmi-területi egyenlötlenségek Magyarországon. Közgazdasági és Jogi Könyvkiadó, Budapest. 127-142. o.

Ráday L. (1993) Adósok és hitelezök: Adalékok a fizetésképtelenség, a csőd-és a felszámolási eljárás kérdéseihez. - Közgazdasági Szemle. 7-8. 646-662. o.

Rechnitzer J. (1993) Szétszakadás vagy felzárkózás. (A térszerkezetet alakitó innovációk). MTA RKK, Györ.

Reke B. (1996) A csődbe jutott mezögazdasági vállalkozások jellemzöi. - Bankszemle. 2. 50-55. o.

Sántha J.-né (1999) A vállalkozási struktúra változásai a kilencvenes években, - Statisztikai Szemle. 5-6. 421-437. 0 .

Szanyi M. (1999) Csöd, felszámolás, végelszámolás mint a privatizáció módja. ÁPV Rt., Budapest. www.foe.hu (Felszámolók és Vagyonfelügyelök Országos Egyesületének internetes honlapja) www.ksh.hu (Központi Statisztikai Hivatal internetes honlapja) 